\title{
NUMERICAL MODELLING OF PRESSURE AND VELOCITY RATES OF FLOWING ENGINE OILS IN REAL PIPE
}

\section{NUMERYCZNE MODELOWANIE CIŚNIENIA I PRĘDKOŚCI PRZEPŁYWU OLEJU SIL- NIKOWEGO PRZEZ PRZEWÓD RUROWY W WARUNKACH RZECZYWISTYCH}

\begin{abstract}
The article deals with the numerical modelling of physical state flowing liquid in a real environment of real technical component (pipe). Specifically it is about to set the pressured and velocity rates along the pipe geometry in a certain places for temperature dependent material (three engine oil with different viscosity class) at three monitored temperatures of flowing medium. The numerical models were created by means finite element method. Observation focused mainly on places behind technical component geometry curvature which are from the point of view of flowing features most interesting.
\end{abstract}

Keywords: numerical modelling, flow, engine oil, temperature, viscosity, density, FEM.

\begin{abstract}
Artykut dotyczy modelowania numerycznego stanu fizycznego cieczy płynacej w rzeczywistym środowisku rzeczywistego elementu technicznego (przewodu rurowego). W szczególności, celem pracy było określenie ciśnienia i prędkości przeptywu materiału, którego właściwości zależa od temperatury, w określonych punktach przewodu rurowego dla trzech monitorowanych temperatur przepływającego czynnika. Do badań użyto trzech typów oleju silnikowego o różnej klasie lepkości. Modele numeryczne tworzono za pomoca metody elementów skończonych. Obserwacje prowadzono głównie w miejscach tuż za zakrzywieniami elementu technicznego, które są najbardziej interesujące z punktu widzenia właściwości przepływu.
\end{abstract}

Slowa kluczowe: modelowanie numeryczne, przeptyw, olej silnikowy, temperatura, lepkość, gęstość, MES.

\section{Introduction}

The great amount of plants, engineers and researches now deal with how to save production costs in the production of certain products. The situation in engineering is same. Lowering material quantity for production can save considerable amount. But there is an issue how to save the material and keep the same quality goods or else production goods safety at the same time. The experimental costs can exceed savings themselves. In this case the numerical modelling can be very well proved [1] and [15].

If the input has a good quality, [13] confirm that result can be very precise in case of using suitably chosen modelled methods. These obtained models can help to engineers to propose such parts which are not uselessly excessive but at the same time they should be safe in accordance to requested standards [14]. Ideal part shapes can be simulated as well both from the statistical view and dynamical view elasticity, firmness, hydrodynamics, aerodynamics, thermodynamics etc. [10].

According to publication [5] the numerical modelling of many physical phenomenon is closely connected to simulation of certain form of velocity by mathematical means. The liquid velocity is related to solutions of various problems which are given by physical simulation.

Mathematical model consists in equations definition which describes processes above. In view of the fact that there are plane twodimensional processes, axially symmetrical or three-dimensional and timely dependent, there are described by partial differential system equations which must be solved by numerical methods. Their use is subjected to broaden knowledge from field of flowing, turbulence, numerical methods, and computer technology. Commercial programme systems can be used to solve flowing. User's task is to assemble correct calculating model which includes some mathematical, psychical and technical principles. It is necessary to find for such a model all input data in valid standards, carry out solution at terminal, and correctly interprets results for next use and also to carry out effective inspection in all phases of all input and output data. User has to categorize all information on geometrical data (two-dimensional or three-dimensional data, topology), external power data and physical data (information about flowing medium and its physical features). User's necessary task is to have knowledge of hydro-mechanics, thermos-mechanics and other science by problem intricacy[2].

In this study is described the numerical modelling of physical state flowing engine oil in a real pipe by means finite element method. Specifically it is about to set the pressured and velocity rates along the pipe geometry. The theoretical idea is that the variation in viscosity and density of liquid causes significant changes in pressure drop and flow density [6] and [7].

\section{Material and Methods}

Engine oil feeding tube for turbo-blower was real technical component in this contribution. This pipe is used intractor engines. Its shape, dimensions and monitored spots beyond geometry curvature are displayed in the Fig. 1.

Quality input data were necessary to obtain for numerical modelling. According to temperature dependent flowing liquid, engine oils with viscosity class $5 \mathrm{~W}-30,10 \mathrm{~W}-40$ and $15 \mathrm{~W}-40$ were chosen. At this engine oil temperature dependence of density and dynamical viscosity dependence was measured. The measured values of dynamical viscosity and density are displayed in Table 1.

Temperature dependence of dynamical viscosity was measured by rotary viscometer Anton Paar DV-3P with temperature sensor Pt100. The standardized spindle R3 was used which is most suitable for measuring liquid with similar viscosity. Temperature range of 


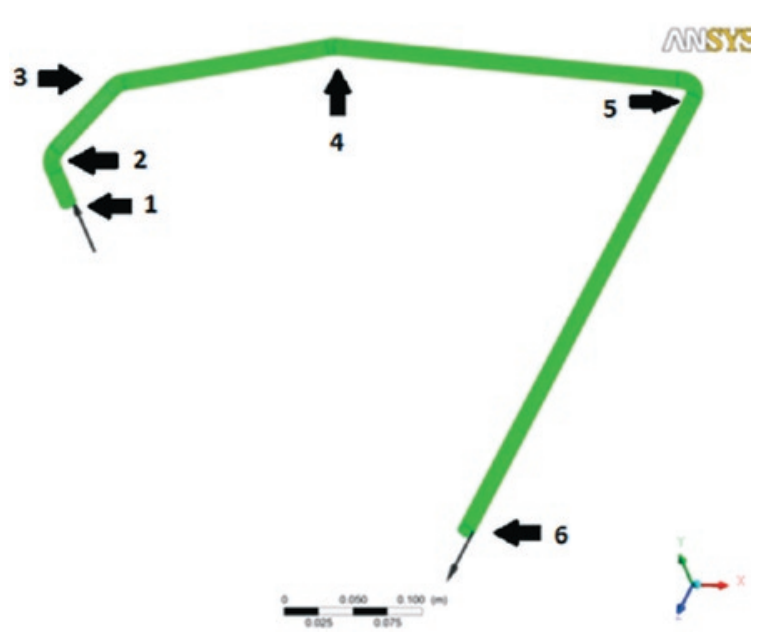

Fig.1. Real technical component (pipe)

measuring was chosen between $-10^{\circ} \mathrm{C}$ and $100^{\circ} \mathrm{C}$, similarly stated by [8] and [9].

Temperature dependence of specific weight (density) was measured by digital hydrometer Densito PX30 with API range for measuring of oil products. Temperature range was chosen between $-10^{\circ} \mathrm{C}$ and $70^{\circ} \mathrm{C}$.

The numerical modelling was done in programme FLUENT, because this program is optimal for finite element method and for Navier-Stokes differential equations solving.

Table 1. Values of dynamic viscosity and density of engine oils at various temperatures

\begin{tabular}{ccccccc}
\hline $\begin{array}{c}\text { Tempera- } \\
\text { ture } \\
\left({ }^{\circ} \mathrm{C}\right)\end{array}$ & \multicolumn{3}{c}{ Density $\left(\mathrm{kg}^{\mathrm{m}} \mathrm{m}^{-3}\right)$} & \multicolumn{3}{c}{ Dynamic viscosity (mPa.s) } \\
\hline-10 & 859 & $86 \mathrm{~W}-40$ & $15 \mathrm{~W}-40$ & $5 \mathrm{~W}-30$ & $10 \mathrm{~W}-40$ & $15 \mathrm{~W}-40$ \\
\hline 0 & 856 & 863 & 871 & 1433 & 2415 & 5298 \\
10 & 852 & 862 & 876 & 374 & 607 & 739 \\
20 & 848 & 860 & 873 & 227 & 306 & 412 \\
30 & 845 & 856 & 870 & 144 & 180 & 225 \\
40 & 838 & 854 & 867 & 89 & 115 & 144 \\
50 & 835 & 852 & 862 & 67 & 85 & 98 \\
60 & 834 & 848 & 858 & 57 & 70 & 74 \\
70 & 833 & 846 & 854 & 49 & 59 & 63 \\
80 & & & & 42 & 53 & 56 \\
90 & & & & 40 & 47 & 52 \\
100 & & & & 38 & 45 & 50 \\
\hline
\end{tabular}

Continuous functions from measured data of dynamical viscosity and density were necessary to create for needs of numerical modelling [6]. Similar work process can be observed at[12].

The exponential function was most suitable function for using of results interpose by general form[11]

$$
\eta=a \exp (b t)
$$

Where $\eta$ is a dynamic viscosity; $t$ is temperature; $a, b$ are coefficients. Values of thesecoefficients are shown in Table $2 . \mathrm{R}^{2}$ is coefficient of determination.
Table 2. Values of coefficients for Eq. (1)

\begin{tabular}{cccc}
\hline Viscosity class of engine oil & $\mathrm{a}(\mathrm{mPa} . \mathrm{s})$ & $\mathrm{b}\left(1 /{ }^{\circ} \mathrm{C}\right)$ & $\mathrm{R}^{2}$ \\
\hline 5W-30 & 790.6 & -0.05976 & 0.9936 \\
$10 \mathrm{~W}-40$ & 1186 & -0.06996 & 0.9955 \\
$15 \mathrm{~W}-40$ & 2379 & -0.08122 & 0.9924 \\
\hline
\end{tabular}

The linear function was chosen as the most suitable function using for results interpose of measured density values [7]:

$$
\rho=c t+d
$$

where $\rho$ is density; $\mathrm{t}$ is temperature; $\mathrm{c}, \mathrm{d}$ are coefficients. Values of these coefficients are shown in Table 3 . $\mathrm{R}^{2}$ is coefficient of determination.

Table 3. Values of coefficients for Eq. (2)

\begin{tabular}{cccc}
\hline Viscosity class of engine oil & $\mathrm{c}\left(1 /{ }^{\circ} \mathrm{C}\right)$ & $\mathrm{d}(\mathrm{mPa} . \mathrm{s})$ & $\mathrm{R}^{2}$ \\
\hline $5 \mathrm{~W}-30$ & -0.3869 & 855.5 & 0.9841 \\
$10 \mathrm{~W}-40$ & -0.2571 & 864.2 & 0.9866 \\
$15 \mathrm{~W}-40$ & -0.3226 & 878.7 & 0.9848 \\
\hline
\end{tabular}

There is a process in the Fig. 2 showing exponential functions interposed measured values of dynamical viscosity. In the Fig. 3 there is a displayed process of linear functions interposed measured density values.

\section{Results and Discussion}

Modelling of pressured profiles, mass flow and velocity of engine oil streaming with viscosity class $5 \mathrm{~W}-30,10 \mathrm{~W}-40$ and $15 \mathrm{~W}-40$ in certain places along geometry of technical component was made by Finite Element Method. There were used general continuity equation, see Eq. (3), and Navier-Stokes equations, see Eq. (4), [5]:

$$
\frac{\partial u}{\partial x}+\frac{\partial v}{\partial y}+\frac{\partial w}{\partial z}=0
$$

$$
\begin{aligned}
& \frac{\partial \mathrm{u}}{\partial \mathrm{t}}+\frac{\partial(\mathrm{uu})}{\partial \mathrm{x}}+\frac{\partial(\mathrm{uv})}{\partial \mathrm{y}}+\frac{\partial(\mathrm{uw})}{\partial \mathrm{z}}=-\frac{1}{\rho} \frac{\partial \mathrm{p}}{\partial \mathrm{x}}+\mathrm{v}\left(\frac{\partial^{2} \mathrm{u}}{\partial \mathrm{x}^{2}}+\frac{\partial^{2} \mathrm{u}}{\partial \mathrm{y}^{2}}+\frac{\partial^{2} \mathrm{u}}{\partial \mathrm{z}^{2}}\right)+\mathrm{f}_{\mathrm{x}} \\
& \frac{\partial \mathrm{v}}{\partial \mathrm{t}}+\frac{\partial(\mathrm{vu})}{\partial \mathrm{x}}+\frac{\partial(\mathrm{vv})}{\partial \mathrm{y}}+\frac{\partial(\mathrm{vw})}{\partial \mathrm{z}}=-\frac{1}{\rho} \frac{\partial \mathrm{p}}{\partial \mathrm{y}}+v\left(\frac{\partial^{2} \mathrm{v}}{\partial \mathrm{x}^{2}}+\frac{\partial^{2} \mathrm{v}}{\partial \mathrm{y}^{2}}+\frac{\partial^{2} \mathrm{v}}{\partial \mathrm{z}^{2}}\right)+\mathrm{f}_{\mathrm{y}} \\
& \frac{\partial \mathrm{w}}{\partial \mathrm{t}}+\frac{\partial(\mathrm{wu})}{\partial \mathrm{x}}+\frac{\partial(\mathrm{wv})}{\partial \mathrm{y}}+\frac{\partial(\mathrm{ww})}{\partial \mathrm{z}}=-\frac{1}{\rho} \frac{\partial \mathrm{p}}{\partial \mathrm{z}}+v\left(\frac{\partial^{2} \mathrm{w}}{\partial \mathrm{x}^{2}}+\frac{\partial^{2} \mathrm{w}}{\partial \mathrm{y}^{2}}+\frac{\partial^{2} \mathrm{w}}{\partial \mathrm{z}^{2}}\right)+\mathrm{f}_{\mathrm{z}}
\end{aligned}
$$

where $\mathrm{u}, \mathrm{v}, \mathrm{w}$ are velocity components; $\mathrm{p}$ is pressure; $\rho$ is density; $v$ is kinematic viscosity; $f_{x, y, z}$ denotes external forces (gravity, centrifugal). Other exact equations are shown in publication [5].

Average pressure values, weight flowing and velocity of engine oil streaming at medium temperature $0^{\circ} \mathrm{C}, 20^{\circ} \mathrm{C}$ and $70^{\circ} \mathrm{C}$ are presented in Table 4, gradually for all six chosen cross-sections.

From calculated data the plummet of pressure can be observed during temperature increase of engine oil flowing as well as increasing of velocity flowing which is related to increase of liquid weight flowing.For illustration were chosen only figures of engine oil with viscosity class $15 \mathrm{~W}-40$.

In the Fig. 4 there are velocity streamlines in cross-sections 1-6 at liquid temperature of $0^{\circ} \mathrm{C}$. In the Fig. 5 there are velocity vectors in cross-sections 1-6 at liquid temperature of $20^{\circ} \mathrm{C}$. In the Fig. 6 there are pressures in cross-sections $1-6$ at liquid temperature of $70^{\circ} \mathrm{C}$. 


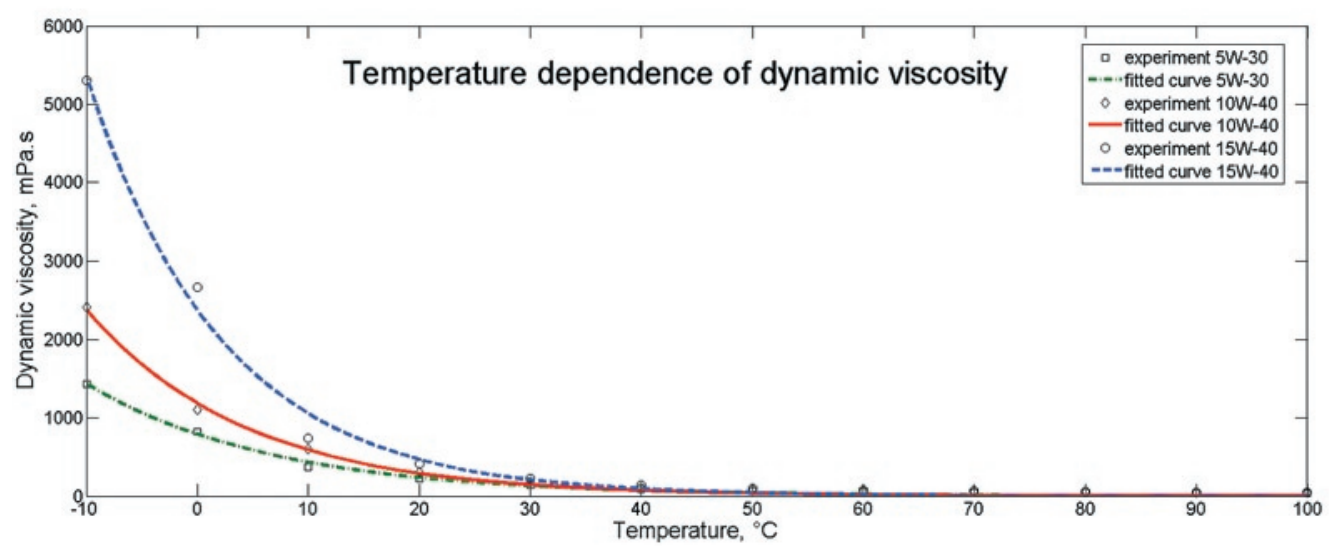

Fig. 2. Temperature dependences dynamic viscosity of engine oils and fitting by exponential function

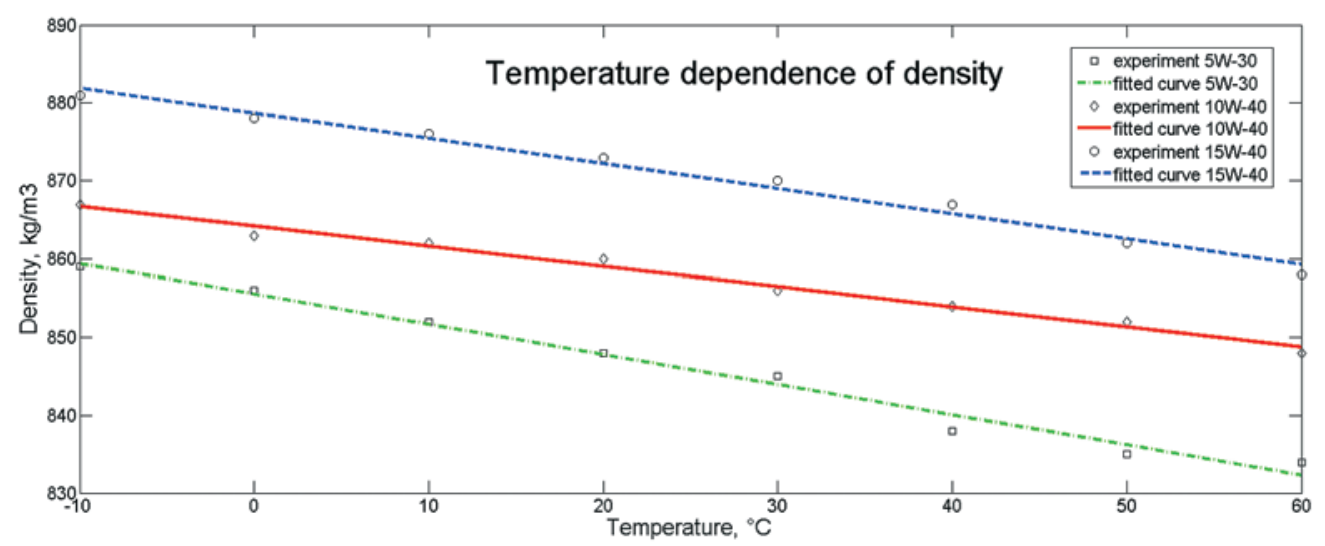

Fig. 3. Temperature dependencesdensity of engine oils density and fitting by linear function

Table 4. Values of pressure, mass flow and velocity of engine streaming for specific temperatures

\begin{tabular}{|c|c|c|c|c|c|c|c|c|c|c|}
\hline & & \multicolumn{3}{|c|}{ Pressure $(\mathrm{kPa})$} & \multicolumn{3}{|c|}{ Mass flow $\left(\mathrm{g} \cdot \mathrm{s}^{-1}\right)$} & \multicolumn{3}{|c|}{ Velocity $\left(\mathrm{m} . \mathrm{s}^{-1}\right)$} \\
\hline $\begin{array}{c}\text { Temp. } \\
\left({ }^{\circ} \mathrm{C}\right)\end{array}$ & $\begin{array}{l}\text { Cross- } \\
\text { section }\end{array}$ & $\sum_{i n}^{\infty}$ & 움 & $\sum_{\substack{n \\
n}}^{\text {o }}$ & $\sum_{i=1}^{0}$ & $\begin{array}{l}\text { 웅 } \\
\text { 3o }\end{array}$ & 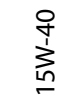 & $\sum_{i n}^{\infty}$ & $\begin{array}{l}\text { 웅 } \\
\text { 3̇ }\end{array}$ & $\sum_{\substack{1 \\
n}}^{+}$ \\
\hline \multirow{6}{*}{0} & 1 & 500.0 & 499.8 & 499.8 & 17.62 & 14.61 & 11.30 & 15.81 & 13.12 & 10.02 \\
\hline & 2 & 472.4 & 468.0 & 465.6 & 18.01 & 15.07 & 11.55 & 15.92 & 13.21 & 10.04 \\
\hline & 3 & 431.2 & 419.5 & 418.7 & 17.65 & 14.69 & 11.34 & 15.86 & 13.17 & 10.04 \\
\hline & 4 & 342.9 & 317.6 & 327.2 & 17.51 & 14.55 & 11.26 & 15.81 & 13.14 & 10.04 \\
\hline & 5 & 194.1 & 176.6 & 184.8 & 17.49 & 14.58 & 11.22 & 15.82 & 13.14 & 10.04 \\
\hline & 6 & 0.002 & 0.002 & 0.001 & 17.53 & 14.61 & 11.29 & 15.82 & 13.14 & 10.04 \\
\hline \multirow{6}{*}{20} & 1 & 499.9 & 499.9 & 499.9 & 17.85 & 16.37 & 16.59 & 16.55 & 14.73 & 14.68 \\
\hline & 2 & 421.8 & 471.4 & 470.7 & 17.97 & 16.78 & 16.98 & 16.60 & 14.86 & 14.81 \\
\hline & 3 & 360.9 & 428.0 & 428.0 & 17.88 & 16.55 & 16.76 & 16.54 & 14.79 & 14.74 \\
\hline & 4 & 279.9 & 336.7 & 337.8 & 17.84 & 16.41 & 16.62 & 16.52 & 14.74 & 14.69 \\
\hline & 5 & 119.1 & 191.4 & 192.8 & 17.83 & 16.36 & 16.56 & 16.53 & 14.75 & 14.70 \\
\hline & 6 & 0.001 & 0.005 & 0.005 & 17.85 & 16.40 & 16.61 & 16.52 & 14.74 & 14.69 \\
\hline \multirow{6}{*}{70} & 1 & 499.9 & 499.9 & 499.9 & 19.12 & 18.92 & 18.18 & 17.04 & 16.62 & 16.02 \\
\hline & 2 & 467.9 & 468.2 & 469.5 & 19.66 & 19.48 & 18.70 & 17.47 & 16.99 & 16.28 \\
\hline & 3 & 432.6 & 433.2 & 434.4 & 18.81 & 18.78 & 18.34 & 17.16 & 16.74 & 16.12 \\
\hline & 4 & 347.6 & 348.5 & 351.2 & 19.10 & 18.97 & 18.36 & 17.08 & 16.66 & 16.04 \\
\hline & 5 & 202.7 & 203.1 & 204.0 & 18.62 & 18.57 & 18.09 & 17.30 & 16.85 & 16.16 \\
\hline & 6 & 0.013 & 0.012 & 0.012 & 19.39 & 19.25 & 18.54 & 17.05 & 16.64 & 16.03 \\
\hline
\end{tabular}



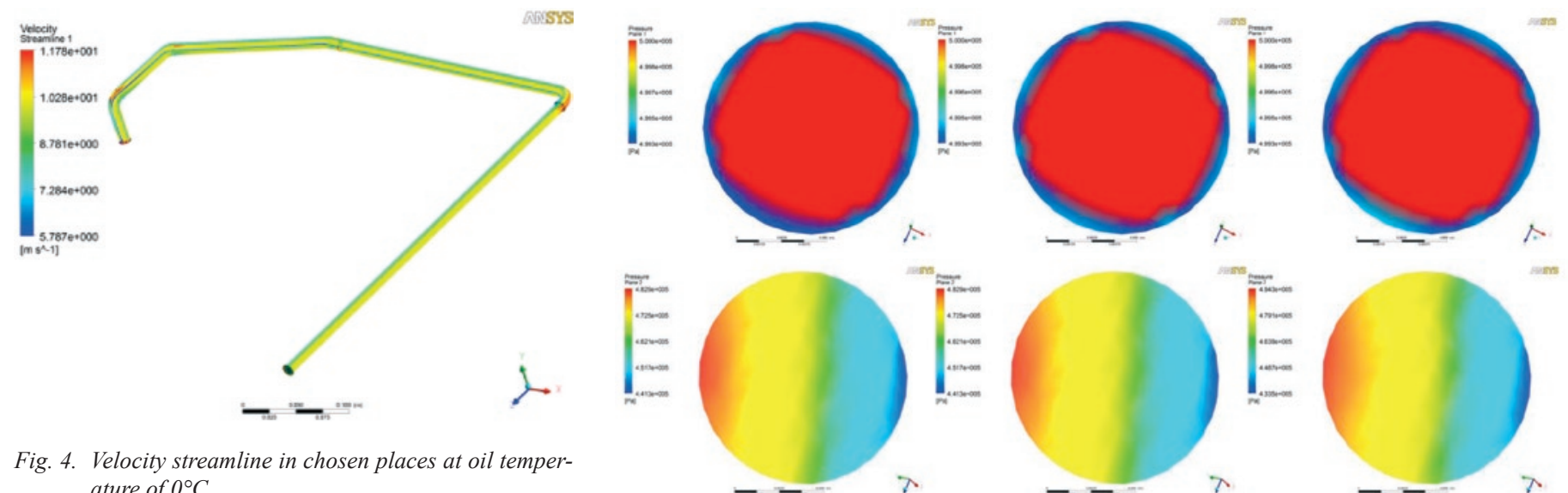
ature of $0^{\circ} \mathrm{C}$
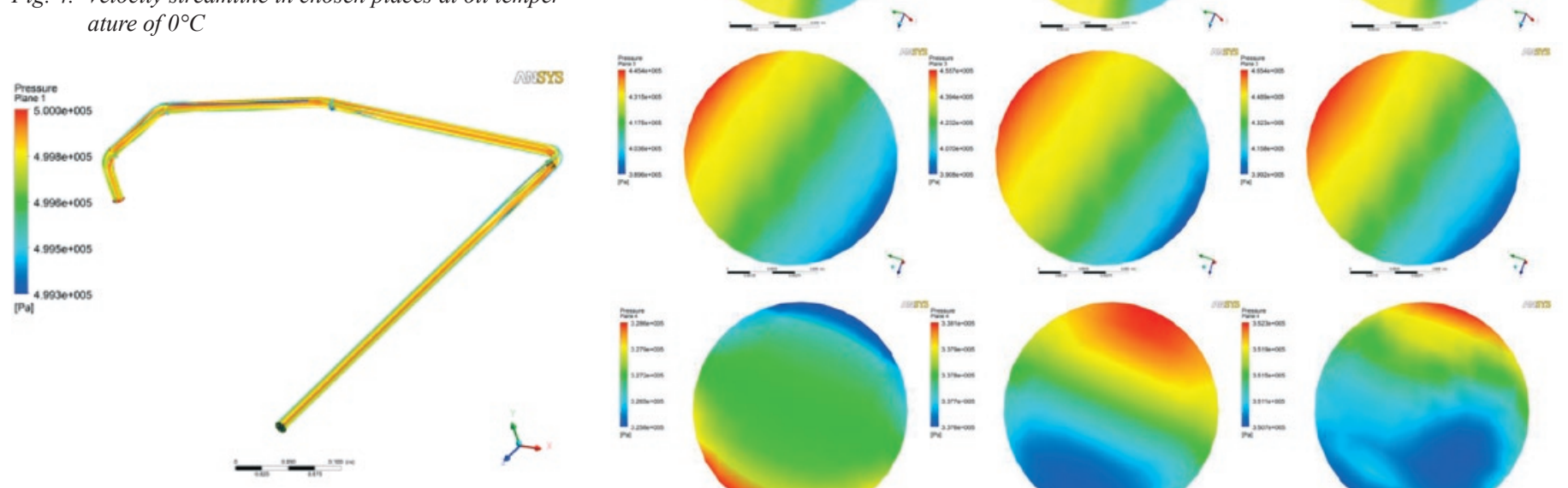

Fig. 5. Velocity vectors in chosen places at oil temperature of $20^{\circ} \mathrm{C}$
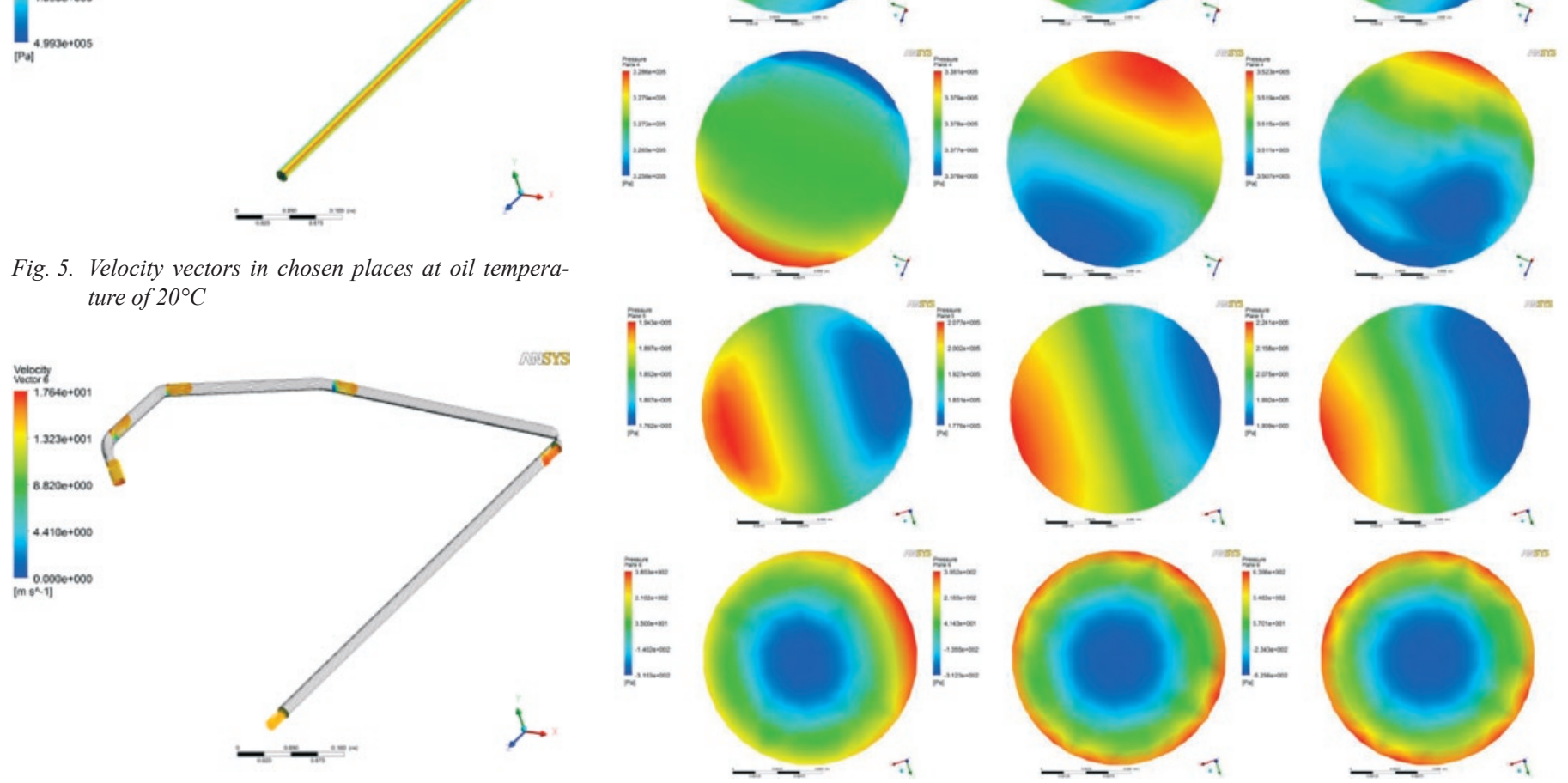

Fig. 6. Pressures in chosen places at oil temperature of $70^{\circ} \mathrm{C}$

Fig. 7. Pressure decomposition in plane of sections $1-6$ at oil temperature of $0^{\circ} \mathrm{C}, 20^{\circ} \mathrm{C}$ and $70^{\circ} \mathrm{C}$

In the Fig. 7 there is a graphical representation of pressure decomposition in chosen cross-sections $1-6$, at liquid temperature $0^{\circ} \mathrm{C}, 20^{\circ} \mathrm{C}$ and $70^{\circ} \mathrm{C}$. During creation of numerical models of pressure decomposition in cross-sections was chosen the smoothest displaying system as in [3] and [4].

In several cross-sections are not any significant differences of pressure at the different temperatures. Only cross-section 4 shows some differences of pressure whole temperatures. It may be caused by high velocity of engine oil, which is lead to turbulent flow.

\section{Conclusion}

Numerical modelling of physical states of streaming liquid in real environment of technical component was made in this article. As a liquid was used engine oil and real technical component was engine oil feed pipe to turbo-blower. This feed pipe is used in tractor engines.
Firstly, the temperature dependence of dynamical viscosity and density of engine oils with viscosity class $5 \mathrm{~W}-30,10 \mathrm{~W}-40$ and $15 \mathrm{~W}-$ 40 was measured by using method of modern measuring devices. These data were interposed suitably chosen regression curved lines - exponential function (viscosity) and linear function (density) - to reach dependence connection which is necessary for numerical modelling.

Also, by using programme there were created numerical models of average values of weight flowing, velocity streaming and decomposition of pressure liquid in six chosen cross sections. These crosssections were suitably chosen - input, output and geometry curving of feed pipe. Numerical modelling was made at temperatures of $0^{\circ} \mathrm{C}$, $20^{\circ} \mathrm{C}$, and $70{ }^{\circ} \mathrm{C}$.

The results of average pressure values, weight flowing and velocity of engine oil streaming at three different temperatures show increasing velocity of flowing liquid with increase of temperature and 
decrease of dynamical viscosity. That is why the weight flowing values of flowing liquid increased.

During numerical modelling creation of pressure decomposition in cross-sections was chosen smoothest displaying system, therefore all colour highlighted pressure values are very precise.

The theoretical idea is that the variation in viscosity and density of liquid causes significant changes in pressure drop and flow density was partially confirmed. With increasing temperature the viscosity and density of engine oil decreased, which was caused higher values of flow velocity and mass flow. This also applies vice versa. Temperature dependence, respectively viscous and density dependence on the pressure drop was not shown.
The results of these experiments can be used for design engineers to predict physical states of engine oil flowing (or similar viscous liquids) in pipe of similar diameter and geometry. The pressure and velocity results are able to predict, which material and what thickness must be used to produce real pipes.

\section{Acknowledgment}

The research has been supported by the project TP 6/2015, financed by Internal Grand Agency AF MENDELU.

\title{
References
}

1. Barata J. Modelling of biofuel droplets dispersion and evaporation, Renewable Energy 2008; 33(4): 769-779, http://dx.doi.org/10.1016/j. renene.2007.04.019.

2. Buchar J, Adamík V, Rolc S. Numerical simulation of the explosive tube fixing, Journal de physique IV 2006; 134: 353-358, http://dx.doi. org/10.1051/jp4:2006134054.

3. Faccini JLH, De Sampaio PAB, Su J. Numerical modelling of stratified gas-liquid flow in inclined circular pipes. International Conference on Nuclear Engineering 2009; 5: 691-696, http://dx.doi.org/10.1115/ICONE17-75986.

4. Jafari M, Mansoori Z, Saffar Avval M, Ahmadi G, Ebadi A. Modeling and numerical investigation of erosion rate for turbulent two-phase gas-solid flow in horizontal pipes. Powder Technology 2014; 267: 362-370, http://dx.doi.org/10.1016/j.powtec.2014.08.004.

5. Kozubková M. Flow modelling of fluids, Ostrava: VŠ̉ TU, 2008. (in Czech)

6. Kumbár V, Dostál P. Temperature dependence density and kinematic viscosity of petrol, bioethanol and their blends, Pakistan Journal of Agricultural Sciences 2014; 51(1): 175-179.

7. Kumbár V, Votava J. Differences in engine oil degradation in spark-ignition and compression-ignition engine, Eksploatacja i Niezawodnosc - Maintenance and Reliability 2014; 16(4): 622-628.

8. Kumbár V, Votava J. Excessive additive effect on engine oil viscosity, Acta Universitatis Agriculturae et Silviculturae Mendelianae Brunensis 2014; 62(5): 1015-1020, http://dx.doi.org/10.11118/actaun201462051015.

9. Maggi CP. Advantages of Kinematic Viscosity Measurement in Used Oil Analysis. Practicing Oil Analysis Magazine 2006 ; 5: 38-52.

10. Mang T, Dresel W. Lubricants and Lubrication, Weinheim: Wiley-vch, 2001.

11. Šedivý P. Temperature dependence of physical quantities, Hradec Králové: KFO press, 2012. (in Czech)

12. Severa L, Havlíček M, Kumbár V. Temperature dependent kinematic viscosity of different types of engine oil, Acta Universitatis Agriculturae et Silviculturae Mendelianae Brunensis 2009; 57(4): 95-102, http://dx.doi.org/10.11118/actaun200957040095.

13. Stevar MSP, Vorobev A. Shapes and dynamics of miscible liquid/liquid interfaces in horizontal capillary tubes, Journal of Colloid and Interface Science 2012; 38(3): 184-197, http://dx.doi.org/10.1016/j.jcis.2012.06.053.

14. Troyer D. Understanding absolute and kinematic viscosity, Practicing Oil Analysis 2002; 1: 15-19.

15. Yamamoto S, Nagaoka M, Ueda R, Wakisaka Y, Noda S. Numerical simulation of diesel combustion with a high exhaust gas recirculation rate, International Journal of Engine Research 2002; 11(1): 17-27, http://dx.doi.org/10.1243/14680874JER05309.

\author{
Vojtěch KUMBÁR \\ Jiří VOTAVA \\ Department of Engineering and Automobile Transport \\ Mendel University in Brno \\ Zemědělská 1/1665, 61300 Brno, Czech Republic \\ E-mail: vojtech.kumbar@mendelu.cz, jiri.votava@mendelu.cz
}

